http://journal.uinsgd.ac.id/index.php/biodjati

\title{
APPLICATION OF BIOLOGICAL NITROGEN FIXATION CYANOBACTERIA TO PADDY PLANT CULTIVATED UNDER DEEP-WATER CULTURE SYSTEM
}

\author{
Dian Hendrayanti ${ }^{1 *}$, Iman Rusmana ${ }^{2}$, Dwi Andreas Santosa ${ }^{3}$, Hamim $^{4}$
}

Received : May 13, 2020

Accepted : September 17, 2020

DOI: 10.15575/biodjati.v5i2.8510

1,2,4 Department of Biology, Faculty of Mathematics and Natural Sciences, IPB University, Jl. Agatis Kampus IPB Dramaga, Bogor, 16680, Indonesia; Tel. +62-251-8622833

${ }^{3}$ Department of Soil Science and Land Resources, Faculty of Agriculture, IPB University, Kampus IPB Darmaga, Bogor 16880, Indonesia

e-mail:

*1dhendra4@gmail.com

irusmana@ipb.ac.id

3dsantosa@indo.net.id

4hamim@apps.ipb.ac.id

*Corresponding author
Abstract. The Biological Nitrogen Fixing (BNF) cyanobacteria can reduce atmospheric nitrogen into ammonium. This ability makes $B N F$ cyanobacteria a potential eco-friendly $N$-source for soil-planted pad$d y$. Apart from a few success stories of BNF cyanobacteria application in the rice field, its role as an ammonium producer is still an open question. There is also a possibility that indeed cyanobacteria biomass which provides nitrogen through the biological decomposing process. This study aimed to analyze the influence of three strains BNF cyanobacteria on paddy grown in the Deep-Water Culture (DWC) hydroponic system. Yoshida Nutrient Solution was used as a growth medium with the application of 0, 45.7, and $91.4 \mathrm{gL}^{-1}$ of ammonium nitrate $\left(\mathrm{NH}_{4} \mathrm{NO}_{3}\right)$ with five replications. The result showed that interaction between cyanobacteria and nitrogen significantly influenced the total nitrogen of paddy plant, but not the paddy plant height, the number of tillers, and biomass. Cyanobacterial filaments were found mostly attached to the paddy root rather than floated in the DWC system. Paddy treated with cyanobacteria had more lateral root than control. The result suggested that cyanobacteria support paddy growth indirectly through nitrogen deposition in plant tissue and root development.

Keywords: cyanobacteria, hydroponic, nitrogen, paddy.

\section{Citation}

Hendrayanti, D., Rusmana, I., Santosa, D. A. \& Hamim. (2020). Application of Biological Nitrogen Fixation Cyanobacteria to Paddy Plant Cultivated Under Deep-Water Culture System. Jurnal Biodjati, 5(2), 164-173.

\section{INTRODUCTION}

Utilization of potential Biological Nitrogen Fixation (BNF) microorganisms to support plant growth has been reported in many works. Azotobacter, Azospirillum, cyanobacteria, and P-solubilizing bacteria are examples of prokaryotic BNF that have been studied as biofertilizer in crops (Malakar et al., 2012). The beneficial effects of these microorganisms as biofertilizer include the addition of available nitrogen and phosphor
(Qureshi et al., 2011; Roy et al., 2017), the supplement of antioxidant enzymes (Essa et al., 2015), the formation of humus (Prasanna et al., 2013), as well as improving soil aggregation (Maqubela et al., 2009). Recently, the application of prokaryotic BNF as biofertilizer gains more and more attention in line with the increasingly widespread environmental issues of crop-soil degradation and water pollution caused by chemical fertilizer. However, the progress of cyanobacteria utilization is not as faster as other microbes such as bac- 


\section{JURNAL BIDDJATI}

http://journal.uinsgd.ac.id/index.php/biodjati

teria and fungi. There are several obstacles, including culture preparation, biomass production, and the distribution of biofertilizer to farmers, which caused BNF cyanobacteria applications were discouraged, as reported in India and Bangladesh (Malakar et al., 2012). Despite those problems, BNF cyanobacteria still have a good opportunity to be used as a prospective BNF due to their feasible contribution as nitrogen-source for some crops.

The potential use of BNF cyanobacteria has been reported because of their well-established role as diazotrophs (Singh et al., 2016), especially in the rice field (Paudel et al., 2012; Begum et al., 2013; Khatun et al., 2012). However, in cyanobacteria groups, the ability of nitrogen fixation mostly belongs to the member of Nostocales and Stigonematales, which possess a nitrogenase enzyme. Their ability to fix nitrogen, causes these microbes to provide available nitrogen to the plants or microbial life present in the soil (Singh et al., 2016). Roger et al. (1987) argued that BNF cyanobacteria supplied nitrogen through the decay of its biomass. The dead cells of cyanobacteria, which contain organic materials, are decomposed by microbial soil and deposited as organic as well as inorganic materials such as amino acids, inorganic phosphate, and others' valuable nutrients for the plant.

The previous experiments showed that the application of BNF cyanobacteria as biofertilizer to paddy plants grown in the soil caused an improvement in the yield of rice, as well as the quality of psycho-chemical properties of soil (Prasanna et al., 2014). However, it is not easy to distinguish the sole effect of cyanobacteria and the measurement of nitrogen fixation in situ, due to the complexity of soil flora. The hydroponic system of DeepWater Culture (DWC) used in this study had several advantages because the measurement of ammonium and observation of cyano- bacteria-root interaction can be carried out easily. Moreover, growing paddy in a hydroponic system with cyanobacteria application has not been reported before. This study aimed to analyze the influence of BNF cyanobacteria on paddy growth in an open hydroponic system.

\section{MATERIALS AND METHODS}

\section{Experimental Design}

The experiment was carried out from January to March 2019. Paddy was cultivated under a Deep-Water Culture (DWC) hydroponic system using 4 (four) L container. Each container contained Yoshida Nutrient Solution (Yoshida et al., 1976) with modification of nitrogen source $\left(\mathrm{NH}_{4} \mathrm{NO}_{3}\right)$ as a treatment. A styrofoam plate with three holes was placed on the top of the container to support the plants. Oxygen supply on the system was provided by inserting the aerator into the container. The surface level of the nutrient solution was maintained every two days, and the $\mathrm{pH}$ was adjusted three times a week. The paddy plants were treated with the addition of nitrogen and cyanobacteria. Plant height and number of tillers were measured once a week. The yield of biomass, total nitrogen, and water content on the tissue were observed at the end of the experiments i.e., 35 days after planting (dap).

A Completely Randomized Design with two factors i.e., nitrogen concentration and cyanobacteria strains were used in the experiment. Three concentrations of nitrogen $\left(\mathrm{NH}_{4} \mathrm{NO}_{3}\right)$ were applied including $\mathrm{A}(0$ $\left.\mathrm{g} / \mathrm{L} \mathrm{NH}_{4} \mathrm{NO}_{3}\right), \mathrm{B}\left(45.7 \mathrm{~g} / \mathrm{L} \mathrm{NH}_{4} \mathrm{NO}_{3}\right)$, and $\mathrm{C}$ $\left(91.4 \mathrm{~g} / \mathrm{L} \mathrm{NH}_{4} \mathrm{NO}_{3}\right)$, while three cyanobacteria strains were: 1 (CSO2 strain), 2 (CSO6 strain), and 3 (CSO13 strain). The amount of each strain inoculant for each treatment was 1 $\mathrm{g}$ (fresh weight). Therefore, in combination, the treatments were as follows: $\mathrm{N}$-treatment 


\section{JURNAL BIDDJATI}

http://journal.uinsgd.ac.id/index.php/biodjati

inoculated with $\mathrm{CSO} 2$ strain (A1, B1, C1); $\mathrm{N}$-treatment inoculated with CSO6 strain (A2, B2, C2); N-treatment inoculated with CSO13 strain (A3, B3, C3); and N-treatments without cyanobacteria inoculant (A0, B0, C0) were provided as controls. Each treatment was repeated five times.

Yoshida Nutrient Solution (without nitrogen source) used in the experiment consisted of macro and micronutrients. The macronutrients were $\mathrm{NH}_{4} \mathrm{NO}_{3}$ (referred to the treatment), $40.3 \mathrm{gL}^{-1} \mathrm{NaH}_{2} \mathrm{PO}_{4}, 71.4 \mathrm{gL}^{-1} \mathrm{~K}_{2} \mathrm{SO}_{4}, 88.6 \mathrm{gL}^{-1}$ $\mathrm{CaCl}_{2}, 324 \mathrm{gL}^{-1} \mathrm{MgSO}_{4} .7 \mathrm{H}_{2} \mathrm{O}$; and micronutrients were $0.074 \mathrm{gL}^{-1}\left(\mathrm{NH}_{4}\right) 6 \mathrm{Mo}_{7} \mathrm{O}_{24}, 1.50$ $\mathrm{gL}^{-1} \mathrm{MnCl}_{2} .4 \mathrm{H}_{2} \mathrm{O}, 0.934 \mathrm{gL}^{-1} \mathrm{H}_{3} \mathrm{BO}_{3}, 0.035$ $\mathrm{gL}^{-1} \mathrm{ZnSO}_{4}, 0.031 \mathrm{gL}^{-1} \mathrm{CuSO}_{4}, 7.7 \mathrm{gL}^{-1} \mathrm{FeCl}_{3}$, and $0.25 \mathrm{gL}^{-1} \mathrm{C}_{6} \mathrm{H}_{8} \mathrm{O}_{7}$. Components of micronutrients were dissolved separately; combining with $50 \mathrm{~mL} \mathrm{H}_{2} \mathrm{SO}_{4}$ concentrate to make up 1 L stock solution (Yoshida et al., 1976). $5 \mathrm{~mL}$ of each compound was added to make $4 \mathrm{~L}$ of the solution. The acidity of the solution $(\mathrm{pH})$ was adjusted to 5.8 .

\section{Preparation of Cyanobacteria Inoculant}

Cyanobacteria strains were cultured on Blue Green 11 liquid medium (Andersen, $2005)$ without nitrogen source (BG110) and placed on a rack at room temperature of 28$30^{\circ} \mathrm{C}$. The culture rack was exposed with 300 lux intensity of continuous light. After incubation for 30 days, the culture was centrifuged to collect the biomass. Inoculant condition was observed using a Stereo Olympus SZX16 wide-zoom microscope and Olympus IX73 light microscope.

\section{Paddy co-Cultivation}

The seeds were selected by soaking them in the water. Floating seeds were eliminated, and the submerged seeds were chosen. The selected seeds were then placed on the tray for germination. The seedlings were kept for 14 days at room temperature. Halfstrength Yoshida Nutrient Solution was added into the tray to keep the growth of seedling until the day of co-cultivation.

For the experiment, the plants with a height of $15-20 \mathrm{~cm}$ were selected. Three individual paddy seedlings were collected together and put into each hole of the container plate, and the containers were randomly placed at the experiment bench outdoor. Paddy was habituated for three days before inoculated with cyanobacteria.

\section{Ammonium Measurement}

The presence of Ammonium was measured using the Nessler reagent color development was prepared following the Standard Method (AWWA, 2002). An $\mathrm{NH}_{4}{ }^{+}$stock solution for the experiment was made by dissolving $3.819 \mathrm{~g}$ anhydrous $\mathrm{NH}_{4} \mathrm{Cl}$, which was previously dried at $103^{\circ} \mathrm{C}$ for three $\mathrm{h}$ in $1 \mathrm{~L}$ water. The $\mathrm{NH}_{4}{ }^{+}$concentration of the final solution is $1 \mathrm{mg}-\mathrm{N} \mathrm{L}^{-1}$ was made by adding a $1 \mathrm{~L}$ deionized water into $1 \mathrm{~mL}$ stock solution. The series of standard solution of $0.01,0.1,0.25$, $0.50,0.75$, and $1.00\left(\mathrm{mg}^{-\mathrm{N} \mathrm{L}} \mathrm{L}^{-1}\right)$ were made from $\mathrm{NH}_{4}{ }^{+}$stock solution. Three $\mathrm{mL}$ Nessler reagent was added to $50 \mathrm{~mL}$ fresh sample then mixed. The UV light absorbance of the final standard solutions and samples was measured at $425 \mathrm{~nm}$ using a Genesys $10 \mathrm{~S}$ Spectrophotometer (Thermo Scientific).

\section{Multivariate Analyses}

Statistical analyses for the data were performed in the statistical computing environment $\mathrm{R}$. The data were separated into two sets: vegetative (plant height, number of tillers, and fresh and dry biomass) and physiological data (total nitrogen and water content). The linearity of all variables on each data was first checked, then analyses were continued with Two-way Multivariate analyses (Two- 


\section{JURNAL BIDDJATI}

http://journal.uinsgd.ac.id/index.php/biodjati

way MANOVA) with the assumption that the data were normal and homogenous. If not, a non-parametric Wilcoxon test would be used to determine the mean squares, degrees of freedom, and significance levels. Differences were considered significant at $\mathrm{P}<0.05$.

\section{RESULTS AND DISCUSSION}

Three strains of cyanobacteria were selected from 12 strains based on their performances of ammonium production and nu- merous biomass (Table 1). The three strains had straight filamentous thallus and heterocyst (Figure 1). Cyanobacteria were applied at 3 days after planting (dap). Under the system, which was equipped with aeration, the filaments of cyanobacteria were floating. But, as the experiment continued, many more filaments were observed being attached to the root. A few days later, the first algal population was observed from the nutrient solution. The alga mostly from Chlorophycean group (Chlorella and Scenedesmus) and few diatoms.

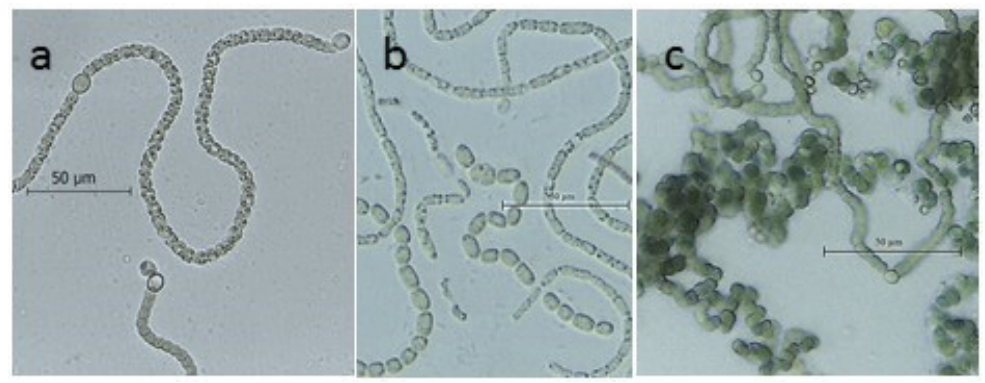

Figure 1. Cyanobacteria strains used for inoculant. a. CSO2; b. CSO6; c. CSO13. Strains CSO2 and CSO6 have loosed and granulated, Filaments, while CSO13 has thickly entwined and smooth filaments.

Table 1. Biomass and ammonium content of 12 cyanobacteria strains

\begin{tabular}{llcc}
\hline \multirow{2}{*}{ Strains } & \multicolumn{1}{c}{ Genus } & Biomass at days of $25(\mathrm{mg} / \mathrm{mL})$ & Ammonium content $(\mathrm{ppm})$ \\
\hline CSO2 & Halotia & $33.6 \pm 22.4$ & $3.10 \pm 2.9$ \\
CSO3 & Desmonostoc & $78.6 \pm 4.7$ & $0.07 \pm 0.00$ \\
CSO4 & Aliinostoc & $32.6 \pm 18.8$ & $0.08 \pm 0.00$ \\
CSO6 & Nostoc & $48.9 \pm 13.9$ & $2.90 \pm 0.8$ \\
CSO7 & Hapalosiphon & $24.7 \pm 6.3$ & $1.01 \pm 0.2$ \\
CSO8 & Calothrix & $46.0 \pm 7.7$ & $1.44 \pm 0.02$ \\
CSO11 & Pelatocladus & $18.7 \pm 4.1$ & $1.40 \pm 0.1$ \\
CSO13 & Desmonostoc & $55.5 \pm 25.2$ & $1.43 \pm 0.00$ \\
CSO15 & Desmonostoc & $33.8 \pm 15.3$ & $2.02 \pm 0.8$ \\
CSO17 & Desmonostoc & $50.8 \pm 12$ & $0.07 \pm 0.00$ \\
CSO20 & Roholtiella & $73.7 \pm 21.2$ & $0.07 \pm 0.00$ \\
CSO21 & Roholtiella & $35.2 \pm 0.2$ & $1.17 \pm 0.1$ \\
\hline
\end{tabular}

Remarks: Identification of strains was based on 16S rRNA gene from previous study (Hendrayanti et al., 2019); values after biomass and ammonium content were SD 


\section{JURNAL BIDDJATI}

http://journal.uinsgd.ac.id/index.php/biodjati

Paddy plants showed different growth upon different media (Figure 2). The plant height on A treatment was slightly increased in the first week then stopped growing. The plant height on B treatment reached 42.8-43.8 $\mathrm{cm}$ at the end of the experiment, while on $\mathrm{C}$ treatment was $43.5-47.2 \mathrm{~cm}$. The number of tillers on B and C treatments was varied (5-10 tillers), but no tiller formation was found on A treatment. Statistical analyses showed that the plant height of paddy was strongly influenced by the application of nitrogen, but not by cyanobacteria. There were no significant differences $(\mathrm{P}<0.05)$ of plants height and the number of tillers between plant's Control and plants with cyanobacteria application.
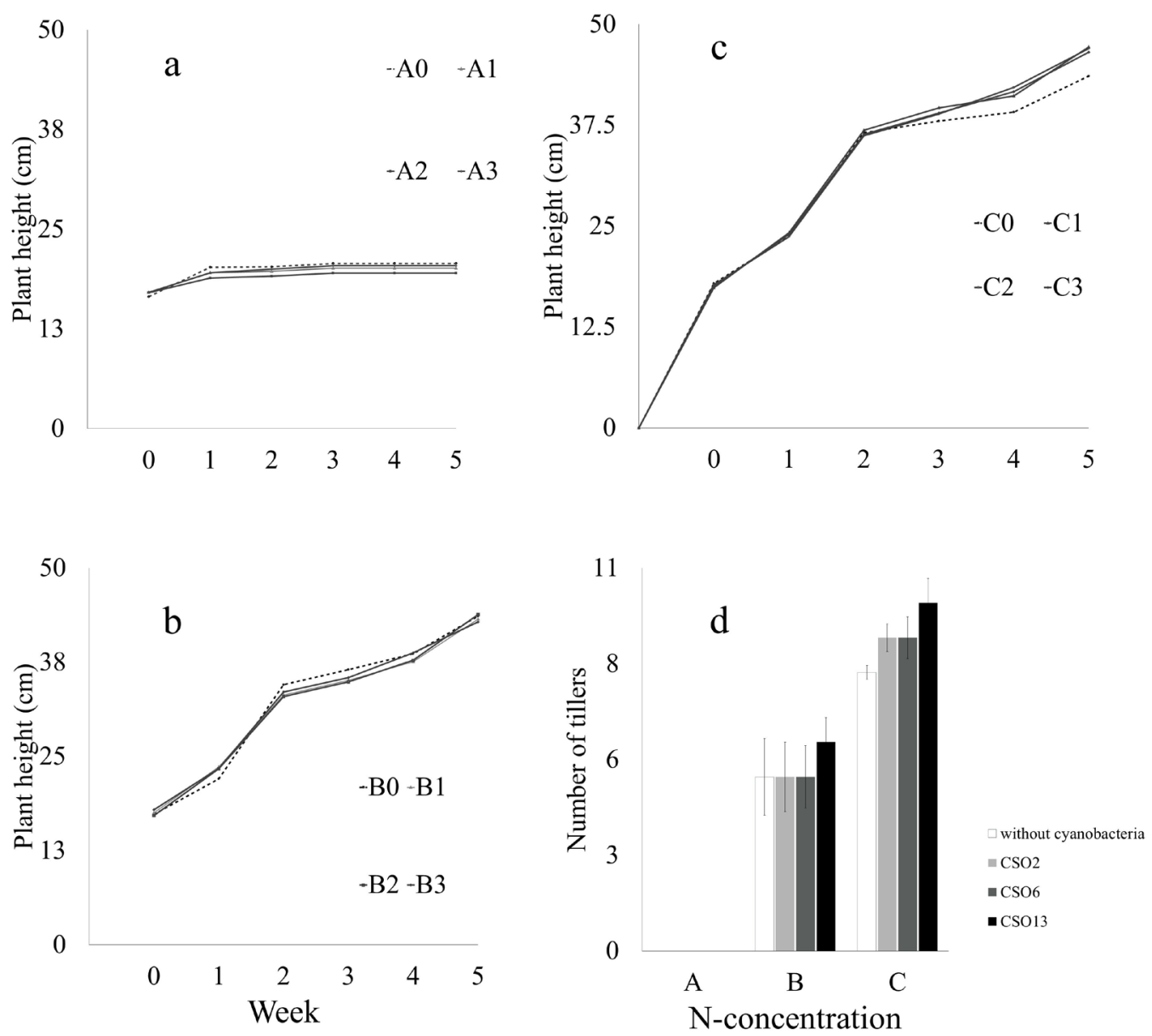

Figure 2. Growth of paddy and the number of tillers. A, B, C showed the treatment of nitrogen concentration. $0,1,2,3$ showed application of cyanobacteria strains. Nitrogen $\left(\mathrm{NH}_{4} \mathrm{NO}_{3}\right)$ concentration: A (0 g/L), B (45.7 g/L), and C (91.4 g/L); Cyanobacteria strains: 0 (no cyanobacteria $=$ control $), 1(\mathrm{CSO} 2), 2(\mathrm{CSO} 6)$, and 3 (CSO13). Bars indicated standard error. 


\section{JURNAL BIDDJATI}

http://journal.uinsgd.ac.id/index.php/biodjati

The effect of nitrogen on the paddy plants was also significant on paddy biomass. The fresh and dry weight of biomass was more affected by nitrogen application than cyanobacteria. The biomass of $\mathrm{A}$ treatment was the lowest compare to $\mathrm{B}$ and $\mathrm{C}$ (Figure $3)$. The fresh biomass of $\mathrm{A}, \mathrm{B}$, and $\mathrm{C}$ treatment were 1.28-1.71 g, 16.51-17.64 g, and 14.54-17.39 g, respectively, while the dry biomass were $0.2 \mathrm{~g}, 2.69-3.04 \mathrm{~g}$, and 4.9-6.11 $\mathrm{g}$ respectively. Figure 3 showed the fresh and dry biomass of shoot and root on each treatment. Shoot fresh weight in B treatment was half of $\mathrm{C}$ treatment, while in A treatment was only $1 / 20$ of $C$. The same trend of the result was obtained on the dry mass of the shoot.
The dry mass of paddy shoot in A and B treatments were much lower compared to $\mathrm{C}$ treatment. These data showed that nitrogen concentration was strongly influenced the paddy biomass. A similar result was presented by Fagaria et al. (2011). Chaudhuri (2015) also reported the reduction of rice root dry weight as a result of nitrogen deficiency. Although nitrogen concentration influenced the fresh and dry biomass of paddy, in contrast, there was no effect of the cyanobacterial application on plant biomass. The absence of cyanobacterial effect on plant growth may be due to the low concentration of cyanobacteria per volume of media.
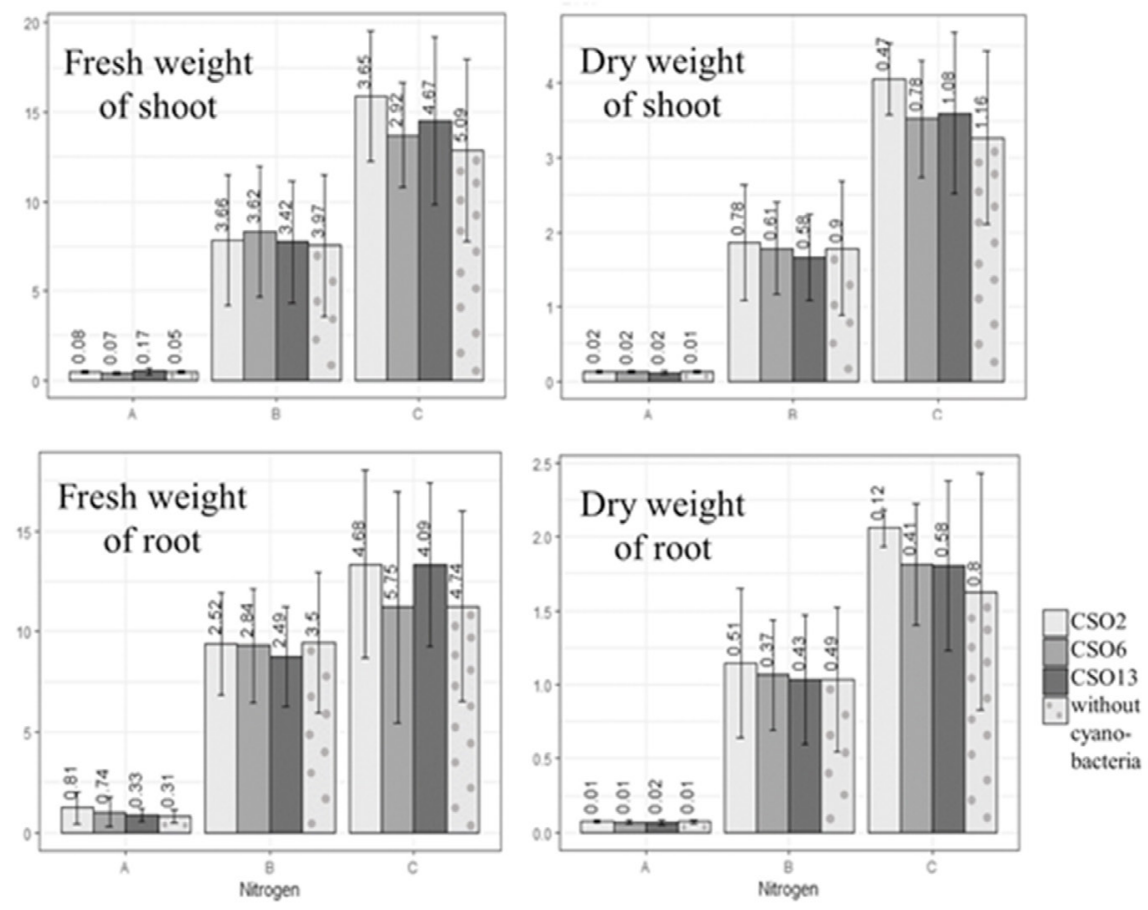

Figure 3. Fresh and dry weight of biomass of shoot and root at the end of experiment (35 dap). Treatment of nitrogen (NH4NO3) concentration: A (0 g/L), B $(45.7 \mathrm{~g} / \mathrm{L})$, and C $(91.4 \mathrm{~g} / \mathrm{L})$; Cyanobacteria strains: 0 (no cyanobacteria $=$ control), 1 (CSO2), 2 (CSO6), and 3 (CSO13). Bars indicated standard error. 


\section{JURNAL BIDDJATI}

http://journal.uinsgd.ac.id/index.php/biodjati

The influence of cyanobacteria, nitrogen, and interaction between the two factors occurred on the total nitrogen of the paddy plant. Although the influence of cyanobacteria amongst the three strains was not significantly different, it was observed that the total nitrogen of paddy applied with strains of CSO6 and $\mathrm{CSO} 13$ in low nitrogen concentration (B treatment) were closed to those in high nitro- gen concentration ( $\mathrm{C}$ treatment) (Table 2). The amount of inoculant biomass is probably one of the challenge factors of microbial $i$ noculation to support plant growth. Biomass of inoculant must be enough to start the increase of microbial population. If the amount of inoculant is too small, other competitors would grow faster and outcompete with the expected microbial population.

Table 2. Total nitrogen (Total-N) paddy and number of lateral roots at the end of experiment

\begin{tabular}{lcccccrrr}
\hline Parameters & B0 & B1 & B2 & B3 & C0 & C1 & C2 & C3 \\
\hline Total-N root $(\%)$ & $0.68 \mathrm{a}$ & $0.72 \mathrm{a}$ & $1.24 \mathrm{~b}$ & $0.97 \mathrm{a}$ & $0.82 \mathrm{a}$ & $0.85 \mathrm{a}$ & $0.96 \mathrm{a}$ & $0.86 \mathrm{a}$ \\
Total-N shoot $(\%)$ & $1.22 \mathrm{ad}$ & $1.12 \mathrm{a}$ & $1.25 \mathrm{acd}$ & $1.24 \mathrm{acd}$ & $1.59 \mathrm{~b}$ & $1.43 \mathrm{bc}$ & $1.40 \mathrm{bd}$ & $1.51 \mathrm{~b}$ \\
$\begin{array}{l}\text { Total N plant }(\%) \\
1.90 \mathrm{a}\end{array}$ & $1.84 \mathrm{a}$ & $2.49 \mathrm{~b}$ & $2.21 \mathrm{c}$ & $2.41 \mathrm{bc}$ & $2.28 \mathrm{bc}$ & $2.36 \mathrm{bc}$ & $2.37 \mathrm{bc}$ \\
$\begin{array}{l}\text { Lateral root } \\
\text { (number per cm) }\end{array}$ & $38 \pm 17$ & $47 \pm 9$ & $49 \pm 6$ & $59 \pm 7$ & $59 \pm 23$ & $65 \pm 5$ & $86 \pm 19$ & $77 \pm 8$ \\
\hline
\end{tabular}

Remarks: Treatment of nitrogen $\left(\mathrm{NH}_{4} \mathrm{NO}_{3}\right)$ concentration: $\mathrm{B}(45.7 \mathrm{~g} / \mathrm{L})$ and $\mathrm{C}(91.4 \mathrm{~g} / \mathrm{L})$; Cyanobacteria strains: 0 (no cyanobacteria=control), $1(\mathrm{CSO} 2), 2$ (CSO6), and 3 (CSO13); values after the number of lateral roots were $\mathrm{SD}$

Interaction of cyanobacteria and paddy root was documented by filaments' attachment to the paddy root (Figure 4). This chemotactic respond, which had been detected since the beginning of the experiment, triggered by root to produce several chemical substances, known as root exudates, such as galactose, glucuronic acid, and amino acid (Bacilio-Jiminez et al., 2003), which were then utilized by many microorganisms including cyanobacteria. Microscopic examination of paddy root showed that paddy with cyanobacteria application had more lateral roots than that of control (Table 2). Since the assimilation of nitrogen mostly occurs in the root, so, the dense roots will give plants more opportunity to absorb more nutrients. Having more lateral roots, therefore, is an advantage for paddy in this study.

In paddy, as soon as the paddy enters the seed maturation period, which takes place about 11-14 weeks after planting, the supply of nitrogen will depend on the nitrogen depoJurnal Biodjati 5(2):164-173, November 2020 sited in plant tissues (Jones et al., 2011). The data of total nitrogen on the fifth week at present study may suggest that the changing of uptake nitrogen from the environment to the $\mathrm{N}$-tissue deposit can be used as guidance of when the application of cyanobacteria should be taken place. As nitrogen in the environment becomes scarce, late inoculation of cyanobacteria might give paddy more benefits in developing paddy roots as well as utilization of heterocyst-produced ammonium to cope with the situation.

The inoculation of cyanobacteria is projected to add ammonium, the $\mathrm{N}_{2}$-fixation product, to the nutrient solution. However, along with the experiment, the ammonium content in the nutrient solution in all treatments was decreased from 0.24 to $0.06 \mathrm{ppm}$. Since in the laboratory experiment, the three strains demonstrated the ability to produce ammonium, probably the transfer process of ammonium as a product of $\mathrm{N}_{2}$-fixation from the cell into the environment needs time 


\section{JURNAL BIDDJATI}

http://journal.uinsgd.ac.id/index.php/biodjati

(Jochum et al., 2018), which may limit the benefits of living BNF cyanobacteria inoculation. Ammonium released from cyanobacteria cells can be quickly absorbed by root and may not be detected at the time nutrient solution analyzed for ammonium content. Another possibility is that ammonium $\left(\mathrm{NH}_{4}{ }^{+}\right)$ may be transformed again into nitrogen gas $\left(\mathrm{N}_{2}\right)$ through nitrification and denitrification processes that naturally happen in an open system.

Overall, the present study using a fully hydroponic system for paddy growth showed that the inoculation of living BNF cyanobacteria influenced the nitrogen deposit of shoot and root of paddy in low nitrogen concentration. Amongst tested cyanobacteria strains, the prospect of strains of CSO6 and CSO13 as nitrogen source need further research with two points consideration: the amount of inoculant biomass and the time of inoculation. Nonetheless, BNF cyanobacteria application must be accompanied by exogenous nitrogen.

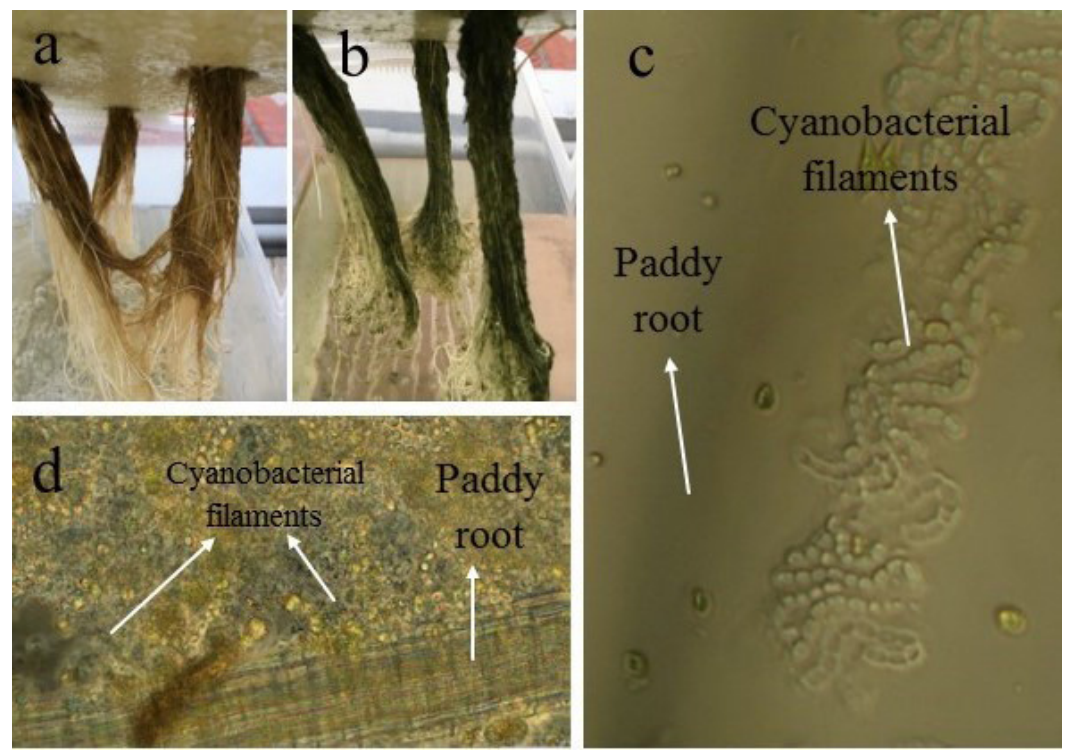

Figure 4. Examination of paddy root. a. Control. b. Paddy treated with cyanobacteria. c -d. Attachment of cyanobacterial filaments to paddy root (seen as black shadowed object) as seen under light microscope (scale: 400x)

\section{ACKNOWLEDGEMENTS}

We would like to thank The Ministry of Research and Technology and Higher Education for the funding through BPP-DN (20152019) to DH.

\section{REFERENCES}

Andersen, R. A. (2005). Algal Culturing Techniques. Elsevier Academic Press.
American Water Work Association. (2002). Simplified Procedures for Water Examination. 5th edition, AWWA.

Bacilio-jimenez, M., Aguilar-flores, S., Ventura-Zapata, E., Perez-campos, E., Bouquelet, S. \& Zenteno, E. (2003). Chemical Characterization of Root Exudates from Rice (Oryza sativa) and Their Effect on the Chemotactic Response of Endophytic Bacteria. Plant Soil, 249, 271-277. 


\section{JURNAL BIDDJATI}

http://journal.uinsgd.ac.id/index.php/biodjati

Begum, Z. N. T., Mandal, R. \& Amin F. (2013). Growth of Cyanobacteria in Saline Soil Amended with NP-fertilizer. Journal of Asian Society Bangladesh Science, 39(2), 167-171.

Chaudhuri, B. P. (2015). Nitrogen Nutrition in Rice. Indian Journal of Plant Sciences, 4(3), 28-37.

Essa, A. M. M., Ibrahim, W. M., Mahmud, R. M. \& ElKassim, N. A. (2015). Potential Impact of Cyanobacterial Exudates on Seed Germination and Antioxidant Enzymes of Crop Plant Seedlings. International Journal of Current Microbiology and Applied Sciences, 4(6), 1010-1024.

Fagaria, N. K., Moreira, A. \& Coelho, A. M. (2011). Yield and Yield Components of Upland Rice as Influenced by Nitrogen Sources. Journal of Plant Nutrition, 34(3), 361-370.

Hendrayanti, D., Rusmana, I., Santosa, D. A. \& Hamim. (2019). Dynamic Population of N2-fixing Cyanobacteria in an Organic Rice Field. Biodiversitas Journal of Biological Diversity, 20(10), 2883-2890.

Jochum, M., Moncayo, L. P. \& Young-Ki, J. (2018). Microalgal Cultivation for Biofertilization in Rice Plants Using a Vertical Semi-closed Airlift Photobioreactor. Plos One, 13(9),1-13.

Jones, C., Olson-Rutz, K. \& Dinkins, P. (2011). Nutrient Uptake Timing by Crops. Montana (USA): Montana State University.

Khatun, W., Ud-Deen, Md. M. \& Kabir, G. (2012). Effect of Cyanobacteria on Growth and Yield of Boro Rice under Different Levels of Urea. Rajshahi University journal of life \& Earth and Agricultural Sciences, 40, 23-29.

Malakar E., Dev Goswami R. C. \& Kalita, M. C. (2012). A Study on Two Poten- tial BGA Isolates Cylindrospermum majus and Nostoc muscorum of Assam, North-East India. Archive Applied Science Research, 4(1), 487-496.

Maqubela, M. P., Mnkeni, P. N. S., Issa, M. O., Pardo, M. T. \& D’Acqui, L. P. (2009). Nostoc Cyanobacterial Inoculation in South African Agricultural Soils Enhances Soil Structure, Fertility and Maize Growth. Plant Soil, 315(1), 79-92.

Paudel, P., Pradhan, S., Pradhan, B., Pant, B. \& Prasad, B. N. (2012). Role of Blue Green Algae in Rice Productivity. Agriculture Biological Journal of North America, 3(8), 332-335.

Prasanna, R., Sharma, R., Sharma, T., Kumar, A., Kumar, R., Gupta, V, Pal, R. K., Shivay, Y. S. \& Nain, L. (2013). Soil Fertility and Establishment Potential of Inoculated Cyanobacteria in Rice Crop Grown under non-Flooded Conditions. Paddy Water Environmental, 11(1), 175-183.

Prasanna, R., Sood, A., Ratha, S. K. \& Singh, P. K. (2014). Cyanobacteria as a "Green" Option for Sustainable Agriculture. In Sharma, N. K., Rai, A. K., \& Staal, L. J. (Eds.). Cyanobacteria an Economic Perspective. Wiley Balckwell, 11(1-4), 175-183.

Qureshi, M. A., Shakir, M. A., Iqbal, A., Akhtar, N. \& Khan, A. (2011). Co-inoculation of Phosphate Solubilizing Bacteria and Rhizobia for Improving Growth and Yield of Mingbean (Vigna radiata L.). Journal of Animals \& Plant Science, 21(3), 491-497.

Roger, P. A., Santiago-Ardales, S., Redd, P. M. \& Watanabe, I. (1987). Impacts of Agricultural Practices on Aquatic Oligochaete Populations in Rice Fields. Biology Fertility Soils, 5, 98-105. 


\section{JURNAL BIDDJATI}

http://journal.uinsgd.ac.id/index.php/biodjati

Roy, M., Saha, S. \& Das, J. (2017). Synergetic Effect of Different Free-living Diazotrophic Bacteria, P-solubilizing Bacteria and Rhizobium on Growth of Oryza sativa L. (cv. NDR - 359). Indian Journal Agricultural Research, 51(3), 221-226.

Sardare, M. D. \& Admane, M. V. (2016). A Review on Plant without SoilHydroponics. International Journal of Research in Engineering and Technology, 2(3), 299-304.
Singh, N. K., Dhar, D. W. \& Tabassum, R. (2016). Role of Cyanobacteria in Crop Protection. Proceeding National Academy Sciences, India Section B: Biological Sciences, 86(1), 1-8.

Yoshida, S., Forno, D. A., Cock, J. H. \& Gomez, K. A. (1976). Laboratory Manual for Physiological Studies of Rice. Manila: The International Rice Research Institute 